Original Article

\title{
EVALUATION OF ANTIMICROSPORIDIAN ACTIVITY OF PLANT EXTRACTS ON NOSEMA CERANAE
}

\author{
Jeong Hwa Kim \\ jin Kyu Park ${ }^{2}$ \\ Jae Kwon Lee ${ }^{1 *}$ \\ ${ }^{1}$ Chungbuk National University \\ Beesen Co. Ltd. \\ * corresponding author: chemokine@cbnu.ac.kr \\ Received: 27 April 2016; accepted: 28 October 2016
}

\begin{abstract}
Nosemosis is one of the most common protozoan diseases of adult bees (Apis mellifera). Nosemosis is caused by two species of microsporidia; Nosema apis and Nosema ceranae. Nosema ceranae is potentially more dangerous because it has the ability to infect multiple cell types, and it is now the predominant microsporidian species in $A$. mellifera. In this study, we identified two anti-nosemosis plants, Aster scaber and Artemisia dubia, which reduced the spore development of $\boldsymbol{N}$. ceranae in spore-infected cells. The most important aspect of our results was that our treatment was effective at non-toxic concentrations. Anti-nosemosis activities of both plants were revealed in honey bee experiments. Specifically, a mixed extract of both $A$. scaber and $A$. dubia showed stronger activity than treatment with each single extract alone. Although the mechanisms of action of $A$. scaber and $A$. dubia against $\boldsymbol{N}$. ceranae are still unclear, our results suggest new medicaments and therapeutic methods to control $N$. ceranae infection.
\end{abstract}

Keywords: Artemisia dubia, Aster scaber, Nosema cerana

\section{INTRODUCTION}

Honey bees are known for manufacturing and keeping honey, as well as building remarkably large cages using wax. As pollinators, honey bees are important to the environment as well as the food supply (Calderone, 2012). There are many species of honey bees spread across the world and they can be seen in many different locations. The honey bee is a member of the genus Apis. The two most important for beekeeping are the western honey bee, Apis mellifera, and the eastern honey bee, Apis cerana.

The genus Nosema, which belongs to the class Microsporidia, contains more than 150 species including Nosema ceranae and Nosema apis which cause Nosemosis (Fries, 2010; Higes, Martin, \& Meana, 2006). A spore of $N$. apis forms in the midgut epithelium of the honey bee. The sporulation of $N$. ceranae is not restricted to the midgut but may also occur in other tissues, including the alimentary canal, malpighian tubules, hypopharyngeal glands, salivary glands, and fat bodies (Chen \& Huang, 2010). N. ceranae is potentially more dangerous because it has the ability to infect multiple cell types, and it is now the predominant microsporidian species in A. mellifera (Williams et al., 2014). In early spring, many dead and weakened honey bees are found around the hive due to the effects of nosemosis.

During the past few decades, there has been little effort to develop a solution to overcome nosemosis. Until recently, fumagillin, which is derived from the microbe Aspergillus fumigatus, was generally used to treat this condition (Whittington \& Winston, 2003). Interestingly, in $N$. apis, fumagillin has been shown to work effectively given proper drug administration (Williams et al., 2008), while the results of $N$. ceranae have been more variable. It has become readily apparent that more research needs to be done to find a suitable antibiotic for $N$. ceranae infection of $A$. mellifera.

Thus, the aim of this work was to develop a new drug against $N$. ceranaeiunder in vitroand in vivo 
environments using different plant extracts of various plants which we listed elsewhere in this manuscript. These plants were selected based on two categories. Category 1, the plants (Mentha arvensis L., Lythrum salicaria L., Schisandra chinensis (Turcz.) Baill., Perilla frutescens var. acuta Kudo, Physalis alkekengi var. francheti (Mast.) Hort, Achillea alpina (Ledeb)) were selected based on their proven antimicrobial activity (Becker et al., 2005; Helvaci et al., 2010; Johnson et al., 2011; Kim, Kim, \& Choi, 2011; Liu, Li, \& Hu, 1983; Mocan et al., 2014), whereas the rest of the plants (Category 2) were an arbitrary collection based on their abundant availability and easy accessibility (Silva et al., 2013).

\section{MATERIAL AND METHODS}

\section{Extraction}

The experimental plants (Amaranthus mangostanys L., Mentha arvensis L., Allium senescens L. var. senescens, Astilboides tabularis (Hemsl.) Engl., Veratrum oxysepalum Turcz., Achyranthes japonica (Miq.) Nakai, Lythrum salicaria L., Symphytum officinale L., Schisandra chinensis (Turcz.) Baill., Perilla frutescens var. acuta Kudo, Physalis alkekengi var. francheti (Mast.) Hort, Rheum undulatum L., Aster scaber Thunberg, Cirsium nipponicum (Maxim.) Makino, Achillea alpina (Ledeb), Disporum uniflorum Baker, Astragalus membranaceus Bunge var. membranaceus, Aster tataricus L.f., and Artemisia dubia Wall.) were purchased from a Kyungdong oriental herbal market in Seoul, Korea, in December 2012. The identification of the plants was performed using the Wild Vegetable Experiment Station, Gangwon ARES, and a voucher specimen (EDU001-EDU019) was stored at Chungbuk National University, Korea. Dried leaves of each plant (100 g) were treated with $50 \%$ ethanol (2 I) three times. We evaporated the solution in vacuo to yield 8-13 $g$ of extract. The crude extract was dissolved with dimethylsulfoxid (Sigma-Aldrich, St. Louis, MO, USA).

\section{Reagents and cells}

The IPL-LD-65Y cell line (IPL cell) was obtained from the Deutsche Sammlung von Mikroorganismen und Zellkulturen (DSMZ, Braunschweig, Germany) and was maintained for routine culture in a TC-100 medium (Sigma-Aldrich) with $11 \%$ fetal calf serum (FCS, Hyclone Laboratories). The cells were seeded at an initial concentration of $2 \times 10^{5}$ cells $/ \mathrm{ml}$ in tissue culture flasks (Nunc, Roskilde, Denmark) and incubated at $27^{\circ} \mathrm{C}$ in a cooling incubator. Cells were routinely passaged every seventh day.

\section{Cell viability test}

Various concentrations $(12.5 \sim 100 \mu \mathrm{g} / \mathrm{mL})$ of the plant extracts were used to treat the IPL cells. Measurement of cell viability was done using the Wst-8 based colorimetric assay (Dojindo, Japan), which relies on the ability of living cells to reduce a tetrazolium salt into a soluble, coloured formazan product. The cell suspension with $5 \times 10^{4}$ cells/well was cultured in triplicate in a flat-bottomed 96-well plate for $96 \mathrm{~h}$. The Wst-8 reagent was added to both the cells and the blank samples, which were then incubated at $37^{\circ} \mathrm{C}$ and $5 \% \mathrm{CO}_{2}$ for $3 \mathrm{~h}$. Next, the level of the dye formed, was measured using a spectrophotometer (Bio-Rad, Hercules, CA) at a wavelength of $450 \mathrm{~nm}$. The blank value without cells was subtracted from each experimental value. Cell viability was expressed by the percentage of live cells compared with that found in the negative controls. The percentage of cell viability was calculated as follows: Cell viability $(\%)=[O D$ level of experiment group/OD level of negative control] $\times 100$.

\section{Isolation of Nosema spores}

Nosema spores were isolated from a naturally infected hive located in the experimental apiary of BEESEN CO., LTD., in Chungnam, Republic of Korea. Isolation of Nosema spores from the honey bee midguts was performed as previously described (Gisder et al., 2011). Briefly, after correction of the contents of the midgut, the bees were macerated in distilled water using a tissue grinder, and the suspension was filtered with a $70-\mu \mathrm{m}$ pore size mesh filter. The large particles in suspension were removed by centrifugation at 12,000 rpm and $1500 \mathrm{rpm}$, and 
then the mixture was re-suspended in distilled water. The number of spores was determined using a hemocy tometer chamber.

\section{Identification of Nosema spores}

A qualitative microscopic diagnosis of spores was performed to detect Nosema-infected bee colonies. To differentiate the spore species, molecular species differentiation was analysed using polymerase chain reaction (PCR), according to the procedure found in previous reports (Genersch et al., 2010; Gisder et al., 2010). Briefly, DNA was isolated using GeneAll Exgene (GeneAll, Seoul, Korea) according to the manufacturer's instructions. The PCR primers used in this study are listed below and were purchased from Bioneer (Daejeon, Korea): sense strand Nosema 5'ggcagttatgggaagtaaca3', anti-sense strand Nosema 5'ggtcgtcacatttcatctct3'; sense strand $N$. ceranae $5^{\prime}$ cggataaaagagtccgttacc3', anti-sense strand $N$. ceranae 5'tgagcagggttctagggat3'; sense strand $N$. apis 5 ' ccattgccggataagagagt3', ant-sense strand $N$. apis 5'cacgcattgctgcatcattgac3'. For each PCR, the following sequence was used: preheat $94^{\circ} \mathrm{C}$ for 2 minutes, $94^{\circ} \mathrm{C}$ for 15 seconds, $60^{\circ} \mathrm{C}$ for 30 seconds, and $72^{\circ} \mathrm{C}$ for 45 seconds, with a final extension phase at $72^{\circ} \mathrm{C}$ for 7 minutes. $A$ variable number of cycles were used to ensure that amplification occurred in the linear phase. The PCR products were separated on a $1.5 \%$ agarose gel and visualised by ethidium bromide staining and ultraviolet irradiation.

\section{Infection of IPL cells and application of test substances}

Infection of Nosema on IPL cells was performed following the methods of previous reports (Gisder et al., 2010; Williams et al., 2008). Spore germination was induced in all the samples as follows: approximately $1 \times 10^{8}$ Nosema spores were suspended in $200 \mu$ of freshly prepared germination buffer (0.5 M sodium chloride, 0.5 $M$ sodium hydrogen carbonate, $\mathrm{pH}$ to 6.0 with orthophosphoric acid) (de Graaf et al., 1993) and incubated at $37^{\circ} \mathrm{C}$ for $15 \mathrm{~min}$ to allow spore germination. Centrifugation at $210 \times g$ for $5 \mathrm{~min}$ was done to harvest the IPL cells. The cell pellet was washed twice with $1 \mathrm{ml}$ of freshly prepared $0.1 \mathrm{M}$ sucrose in 1xphosphate-buffered saline (PBS) and re-suspended in a sucrose buffer at a concentration of $2.5 \times 10^{7}$ cells $/ \mathrm{ml}$. The germinating spores $\left(1 \times 10^{8}\right)$ were re-suspended in $100 \mu \mathrm{lPL}$ cell suspension $\left(2.5 \times 10^{6}\right.$ cells), and the cell-spore suspension was incubated for 5 min at room temperature. Infected cells were re-suspended in $9.5 \mathrm{ml}$ of a TC-100 cell culture medium supplemented with 11\% FCS, $250 \mu \mathrm{g} / \mathrm{ml}$ penicillin/streptomycin, and $250 \mu$ of antibiotic/ antimycotic-solution (Sigma Aldrich). Finally, a careful transfer was done of $100 \mu$ of the cell suspension $\left(2.5 \times 10^{4}\right.$ infected cells) into each well of a 96-well microplate. For evaluation, $1 \mu$ of each plant extract was added to the infected cells to achieve the desired final concentrations (50 and $100 \mu \mathrm{g} / \mathrm{mL}$ ). Cells were incubated for $72 \mathrm{~h}$ at $27^{\circ} \mathrm{C}$ and, subsequently, their infection status was determined independently both via PCR and microscopic analysis.

\section{Experimental design for the in vivo study}

At least 300 healthy bees were collected from each of the three different source colonies, carefully transferred into two mesh cages $\left(16.5 \times 16.5 \times 48\right.$-inches), and stored at $33 \pm 1^{\circ} \mathrm{C}$. Microscopic analysis was used to identify any bees that remained uninfected. One group was bulk fed only a $50 \%$ sucrose solution, whereas the other group was bulk fed a concentration of $1 \times 10^{7}$ Nosema spores mixed in $1 \mathrm{ml}$ of $50 \%$ sucrose solution to induce an infection within $48 \mathrm{~h}$. In vivo toxicity tests of $A$. scaber Thunberg and $A$. dubia Wall. were performed on uninfected (healthy) bees. After weak anesthetisation with $\mathrm{CO}_{2}$ to make handling easier, each experimental group was divided into 20 bees. The treatment groups were fed $A$. scaber Thunberg, $A$. dubia Wall., or $A$. scaber Thunberg + A. dubia Wall. with $1 \mathrm{ml}$ of $60 \%$ sucrose solution for 10 days. To assess their degree of infection, the midguts were introduced into antiseptic microtubes filled with $200 \mu$ distilled water. After thorough grinding, the spores were counted using a hemocytometer and a phase-contrast microscope. 


\section{RESULTS}

\section{Identification of Nosema spores}

Nosema spores were isolated from the naturally infected bees. The midgut of all infected bees was macerated in distilled water, and then the Nosema spores were isolated by filtration and centrifugation. As shown in Fig. 1, the isolated spores had a similar shape (spindle) as those described in previous reports (Gisder et al., 2010).

\section{Identification of Nosema species}

To differentiate the spore species, molecular species differentiation was analysed with PCR according to the procedure of a previous report (Gisder et al., 2011; Whittington \& Winston, 2003). DNA was extracted from $1 \times 10^{4}$ Nosema spores and then amplified with specific primers for $N$. ceranae or $N$. apis, and a universal primer (Nosema spp) for $N$. ceranae and $N$. apis. As shown in Fig. 2, DNA from the isolated spores was amplified with a universal Nosema primer and an N. ceranae primer. However, DNA was not amplified using an $N$. apis primer. This result indicated that the spores isolated from the midgut of bees was $N$. ceranae.

\section{Cell viabilities of plant extracts on IPL cells}

A previous study (Gisder et al., 2010), demonstrated the availability of an IPL cell culturebased screening assay for substances active against Nosema species. For such an assay, verification of the substances' toxicity is a pre-
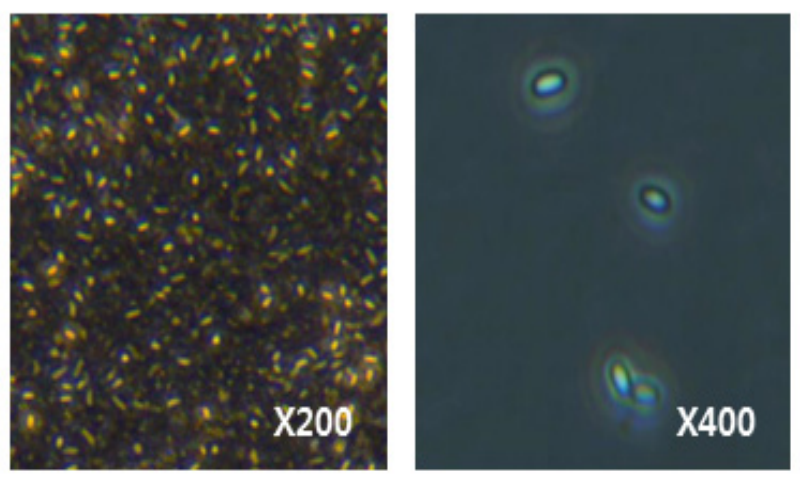

Fig. 1. Microscopic analysis of Nosema spores. A Nosema spores were isolated from the midgut of honey bees. Representative pictures of Nosema spores are shown. requisite. Therefore, we performed our initial experiments to demonstrate the cytotoxicity of each extract. Cytotoxicities of plant extracts on IPL cells were measured in a broad concentration range of $12.5-100 \mu \mathrm{g} / \mathrm{ml}$ using Wst-8 assays. Cells were treated with plant extract for $96 \mathrm{~h}$ after treatment. The negative control (cell only) group was treated only with dimethyl sulfoxide (DMSO) as a solvent for all extracts; 0.99\% DMSO was neither cytotoxic nor active against IPL cells and thus did not influence the analysis of our experiments. As shown in Tab. 1, each extract showed a different cytotoxicity depending on the concentrations. The following showed cytotoxic effects at high concentrations: A. mangostanys L., M. arvensis L., $A$. senescens L. var. senescens, $A$. tabularis (Hemsl.) Engl., $V$. oxysepalum Turcz., A. japonica (Miq.) Nakai, L. salicaria L., S. officinale L., S. chinensis (Turcz.) Baill., P. frutescens var. acuta Kudo, P. alkekengi var. francheti (Mast.) Hort, and $R$. undulatum L. However, A. scaber Thunberg, C. nipponicum (Maxim.) Makino, A. alpina (Ledeb), D. uniflorum Baker, $A$. membranaceus Bunge var. membranaceus, $A$. tataricus L.f., and A. dubia Wall. did not influence cell viability, even at high concentrations. To rule out an effect of the toxic extract on the IPL cells in live bees, we used extracts of $A$. scaber Thunberg, C. nipponicum (Maxim.) Makino, $A$. alpina (Ledeb), $D$. uniflorum Baker, $A$. membranaceus Bunge var. membranaceus, $A$. tataricus L.f., and $A$. dubia Wall. for screening of anti-nosemosis activity.

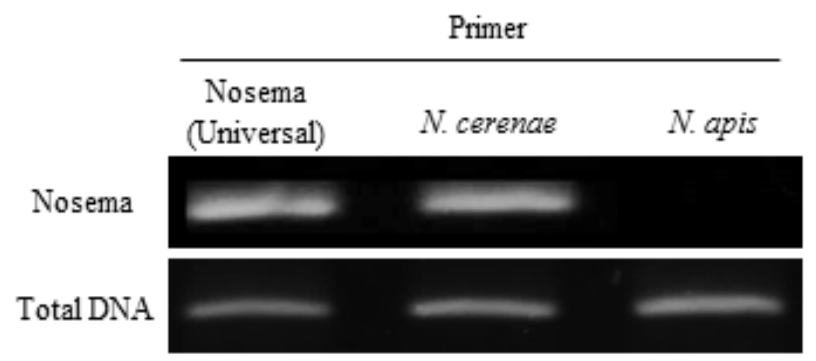

Fig. 2. Results of PCR analysis with a universal primer for Nosema species, specific primers for $N$. Ceranae, and specific primers for $N$. Apis. DNA was extracted from $1 \times 10^{4}$ spores, and then the amplified region indicated the specific primer. PCR analyses using a specific primer were performed in triplicate, and all findings showed similar results. 
Table 1

The proportion of viable IPL cells (\%) after treatments with plant extracts

\begin{tabular}{|c|c|c|c|c|c|}
\hline \multirow{2}{*}{ Name } & \multicolumn{5}{|c|}{ Concentration $(\mu \mathrm{g} / \mathrm{mL})$} \\
\hline & 0 & 12.5 & 25 & 50 & 100 \\
\hline Aster scaber Thunberg & $102 \pm 12$ & $98 \pm 9.2$ & $99 \pm 5.3$ & $101 \pm 7.3$ & $106 \pm 11$ \\
\hline $\begin{array}{c}\text { Cirsium nipponicum (Maxim.) } \\
\text { Makino }\end{array}$ & $98 \pm 11$ & $109 \pm 11$ & $97 \pm 6.6$ & $95 \pm 6.3$ & $97 \pm 9.3$ \\
\hline Amaranthus mangostanys L. & $104 \pm 9.4$ & $97 \pm 2.1$ & $96 \pm 9.1$ & $85 \pm 6.9$ & $88 \pm 12$ \\
\hline Achillea alpina (Ledeb) & $99 \pm 15$ & $96 \pm 1.2$ & $101 \pm 4.7$ & $102 \pm 12$ & $99 \pm 7.8$ \\
\hline Disporum uniflorum Baker & $100 \pm 13$ & $108 \pm 5.2$ & $102 \pm 5.2$ & $99 \pm 4.2$ & $96 \pm 12$ \\
\hline Mentha arvensis L. & $102 \pm 5.2$ & $91 \pm 3.9$ & $87 \pm 9.4$ & $90 \pm 5.4$ & $85 \pm 9.5$ \\
\hline $\begin{array}{l}\text { Astragalus membranaceus } \\
\text { Bunge var. membranaceus }\end{array}$ & $105 \pm 5.9$ & $101 \pm 10$ & $99 \pm 3.8$ & $98 \pm 7.9$ & $101 \pm 7.9$ \\
\hline $\begin{array}{c}\text { Allium senescens } \mathrm{L} \text {. var. } \\
\text { senescens }\end{array}$ & $99 \pm 5.2$ & $86 \pm 5.4$ & $85 \pm 8.5$ & $82 \pm 4.3$ & $82 \pm 4.5$ \\
\hline $\begin{array}{c}\text { Astilboides tabularis (Hemsl.) } \\
\text { Engl. }\end{array}$ & $100 \pm 4.9$ & $90 \pm 4.4$ & $82 \pm 4.5$ & $79 \pm 4.4$ & $75 \pm 5.2$ \\
\hline Veratrum oxysepalum Turcz. & $98 \pm 9.3$ & $95 \pm 5.3$ & $90 \pm 5.3$ & $82 \pm 4.8$ & $78 \pm 8.9$ \\
\hline $\begin{array}{c}\text { Achyranthes japonica (Miq.) } \\
\text { Nakai }\end{array}$ & $99 \pm 3.2$ & $88 \pm 4.3$ & $80 \pm 5.2$ & $72 \pm 5.2$ & $72 \pm 5.2$ \\
\hline Lythrum salicaria L. & $100 \pm 9.6$ & $97 \pm 4.5$ & $95 \pm 4.3$ & $80 \pm 4.9$ & $74 \pm 9.1$ \\
\hline Aster tataricus L.f. & $99 \pm 8.9$ & $101 \pm 6.2$ & $98 \pm 4.9$ & $99 \pm 9.9$ & $99 \pm 5.8$ \\
\hline Symphytum officinale L. & $100 \pm 9.4$ & $83 \pm 5.3$ & $82 \pm 1.3$ & $76 \pm 4.1$ & $70 \pm 4.3$ \\
\hline $\begin{array}{c}\text { Schisandra chinensis (Turcz.) } \\
\text { Baill. }\end{array}$ & $99 \pm 9.3$ & $97 \pm 4.5$ & $88 \pm 5.3$ & $85 \pm 9.5$ & $83 \pm 3.3$ \\
\hline $\begin{array}{l}\text { Perilla frutescens var. acuta } \\
\text { Kudo }\end{array}$ & $98 \pm 8.2$ & $91 \pm 5.4$ & $88 \pm 5.3$ & $88 \pm 4.3$ & $80 \pm 5.2$ \\
\hline $\begin{array}{l}\text { Physalis alkekengi var. } \\
\text { francheti (Mast.) Hort }\end{array}$ & $108 \pm 5.2$ & $97 \pm 4.3$ & $88 \pm 5.4$ & $89 \pm 9.3$ & $85 \pm 4.3$ \\
\hline Rheum undulatum L. & $104 \pm 11$ & $97 \pm 4.4$ & $87 \pm 12$ & $90 \pm 4.7$ & $83 \pm 11$ \\
\hline Artemisia dubia Wall. & $99 \pm 2.5$ & $101 \pm 4.4$ & $103 \pm 12$ & $107 \pm 12$ & $99 \pm 12$ \\
\hline
\end{tabular}

Screening of anti-nosemosis compound in L.f., and A. dubia Wall.). As shown in Tab. 2, the plant extracts

In this study we intended to find an anti-nosemosis drug, which would have few or no cytotoxic effects on live bees. To this end, we performed an IPL cell culture-based screening assay for substances which possess low cytotoxic compounds active against $N$. ceranae $(A$. scaber Thunberg, C. nipponicum (Maxim.) Makino, $A$. alpina (Ledeb), D. uniflorum Baker, A. membranaceus Bunge var. membranaceus, $A$. tataricus band intensities of the DNA band of $N$. ceranae were decreased by treatment with the $A$. scaber Thunberg or $A$. dubia Wall. extracts. These results indicate that the number of Nosema spores was decreased by treatment with $A$. scaber Thunberg or $A$. dubia Wall. However, extracts from $C$. nipponicum (Maxim.) Makino, A. alpina (Ledeb), $D$. uniflorum Baker, $A$. membranaceus Bunge var. membranaceus, and $A$. tataricus L.f. did not influence the DNA band intensity of $N$. ceranae. 
Effect of plants extract on the development of Nosema ceranae

\begin{tabular}{|c|c|c|c|c|}
\hline \multirow{3}{*}{ Name } & \multicolumn{4}{|c|}{ Band intensity } \\
\hline & \multirow[t]{2}{*}{$\begin{array}{l}\text { IPL cell } \\
\text { only }\end{array}$} & \multicolumn{3}{|c|}{$\begin{array}{c}\text { IPL cell+Spore } \\
\text { Concentration }(\mu / \mathrm{g} / \mathrm{mL})\end{array}$} \\
\hline & & 0 & 50 & 100 \\
\hline Aster scaber Thunberg & 0 & 42.4 & 28.3 & 22.5 \\
\hline Cirsium nipponicum (Maxim.) Makino & 0 & 50.2 & 49.3 & 51.1 \\
\hline Achillea alpina (Ledeb) & 0 & 49.7 & 48.2 & 46.1 \\
\hline Disporum uniflorum Baker & 0 & 46.1 & 41.2 & 45.2 \\
\hline Astragalus membranaceus Bunge var. membranaceus & 0 & 51.8 & 49.2 & 46.8 \\
\hline Aster tataricus L.f. & 0 & 47.1 & 44.2 & 46.2 \\
\hline Artemisia dubia Wall. & 0 & 44.3 & 39.3 & 24.2 \\
\hline
\end{tabular}

PCR analyses using a specific primer of Nosema ceranae were performed in triplicate, and all of the performances showed similar results. Each PCR band was digitised and expressed as an intensity.

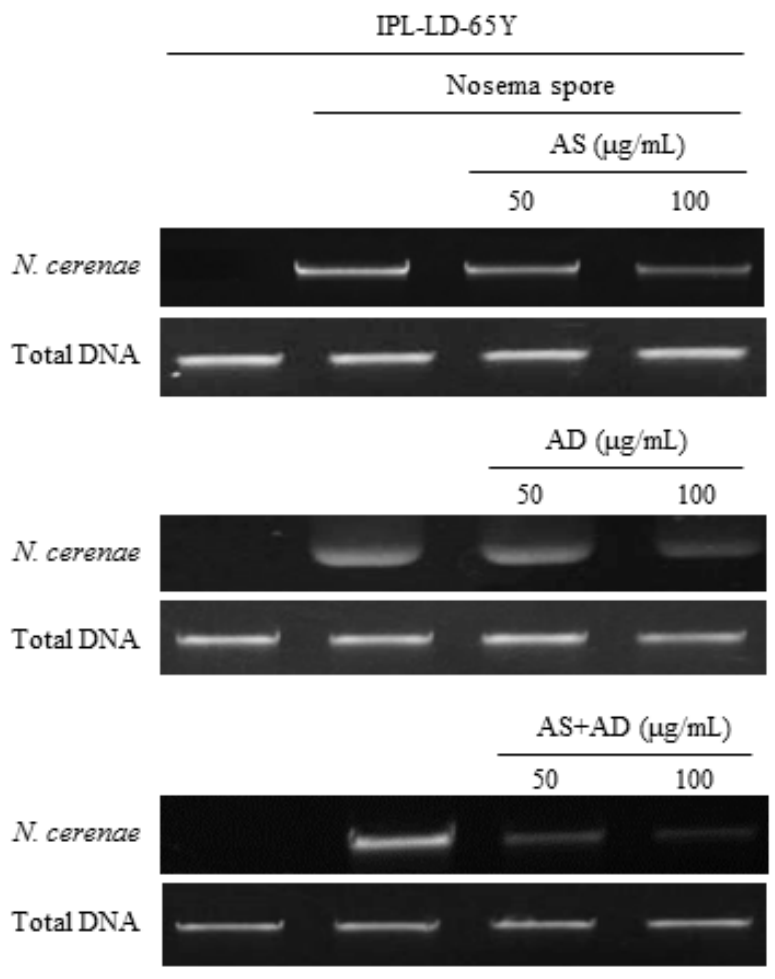

Fig. 3. Effect of $A$. scaber (AS), $A$. dubia (AD), and $A$. scaber $+A$. dubia (AS+AD) on the development of $N$. ceranae. Germinated spores of $N$. ceranae were mixed with IPL-LD-65Y cell line suspension and then treated with plant extracts. PCR analyses using a specific primer were performed in triplicate, and all of them produced similar results.
Fig. 3 shows the representative anti-nosemosis data of $A$. scaber Thunberg (AS) or $A$. dubia Wall. (AD). The thickness of the PCR bands of $N$. ceranae were reduced in a dose dependent manner by AS and AD. We also demonstrated anti-nosemosis activity of the AS and AD mixture. To make this $A S$ and $A D$ mixture, equal amounts of dry plants of AS and AD were combined and then extracted following the description in the Materials and Methods section. Interestingly, the mixture of AS and AD showed stronger activity than either a single substance of $A S$ or $A D$, for reducing the number of nosema infections.

\section{In vivo activity of $\mathrm{A}$. scaber (AS), and $\mathrm{A}$. dubia (AD)}

In advance of this live bee experiment, an in vivo toxicity test was performed first. Healthy bees were divided into five groups and then treated with various concentration of $A S, A D$, or $A S+A D$ mixed in $1 \mathrm{ml}$ of $60 \%$ sucrose solution for 10 days. Dimethoate was used as a highly cytotoxic agent. In the untreated colony, only one bee died before the end of the experiment (Fig. 4). However, all bees that received dimethoate died, even at low concentrations. The feeding of AS or AD with a $60 \%$ sucrose solution had no influence on the survival rate of bees until a concentration of $25 \mu \mathrm{g} / \mathrm{ml}$ was reached. However, giving 50 and $100 \mu \mathrm{g} / \mathrm{ml}$ of 


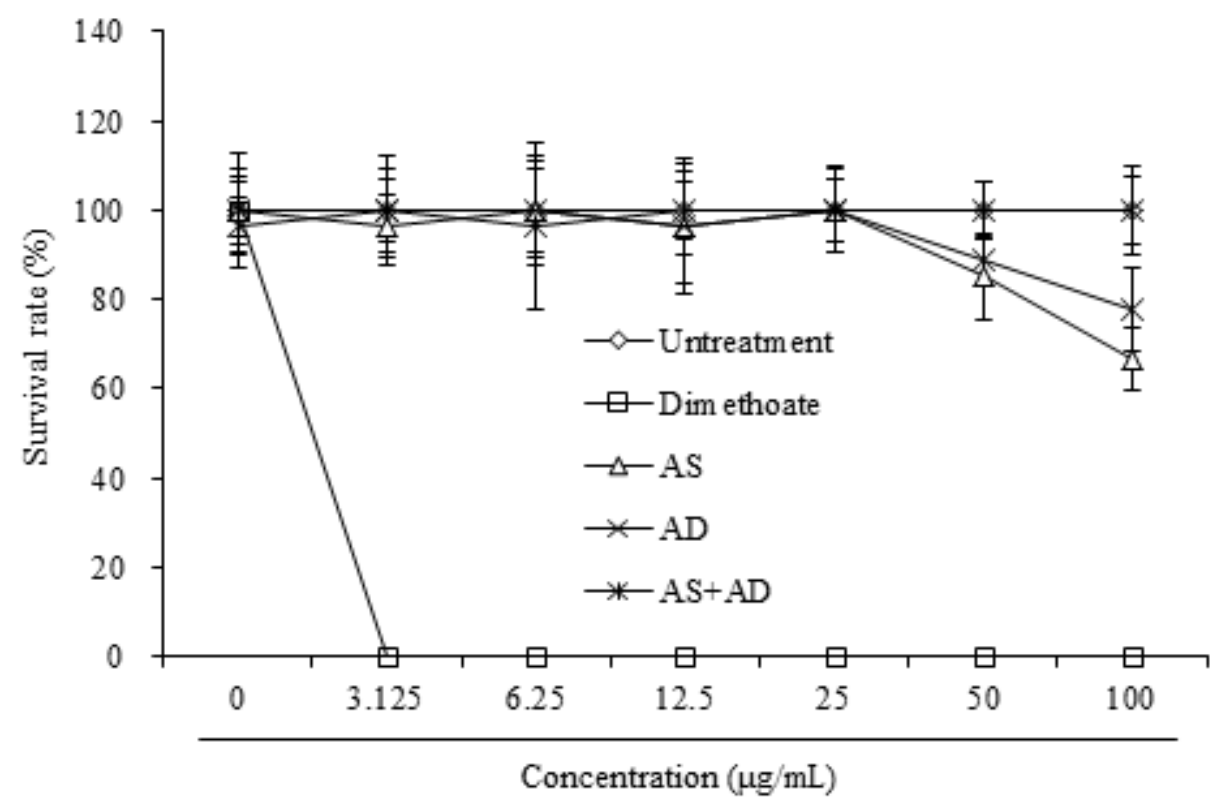

Fig. 4. In vivo toxicity of $A$. dubia (AD), and in vivo toxicity of $A$. scaber (AS). Healthy bees were divided into five groups and then treated with various concentration of $A S, A D$, or $A S+A D$ mixed with of $60 \%$ sucrose solution for 10 days. The bees' survival rate was calculated as follows: Survival rate $(\%)=[($ number of live bees)/(total number of bees) $] \times 100$. The values that are shown are the means \pm SDs of the three independent experiments.

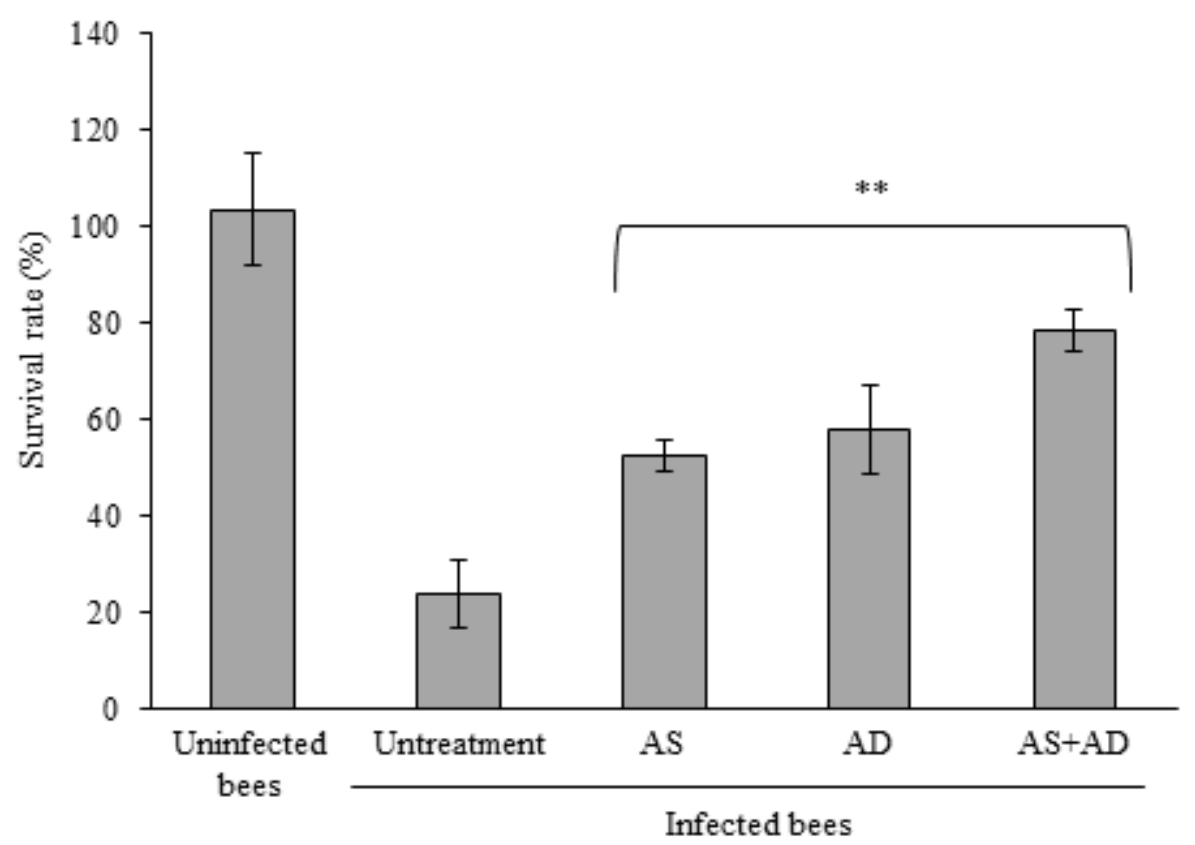

Fig. 5. The influence of $A$. dubia (AD), and the influence of $A$. scaber(AS) on the survival rate of bees infected with $N$. ceramae. In this study, bees that had been infected by $N$. ceramae were treated with $A S, A D$, or $A S+A D$ in a $60 \%$ sucrose solution for 10 days, and then the survival rate of the bees was calculated. The values that are shown are the means \pm SDs of the three independent experiments. *p $<0.05 ; * * p<0.01$ as compared to the untreated bees. 

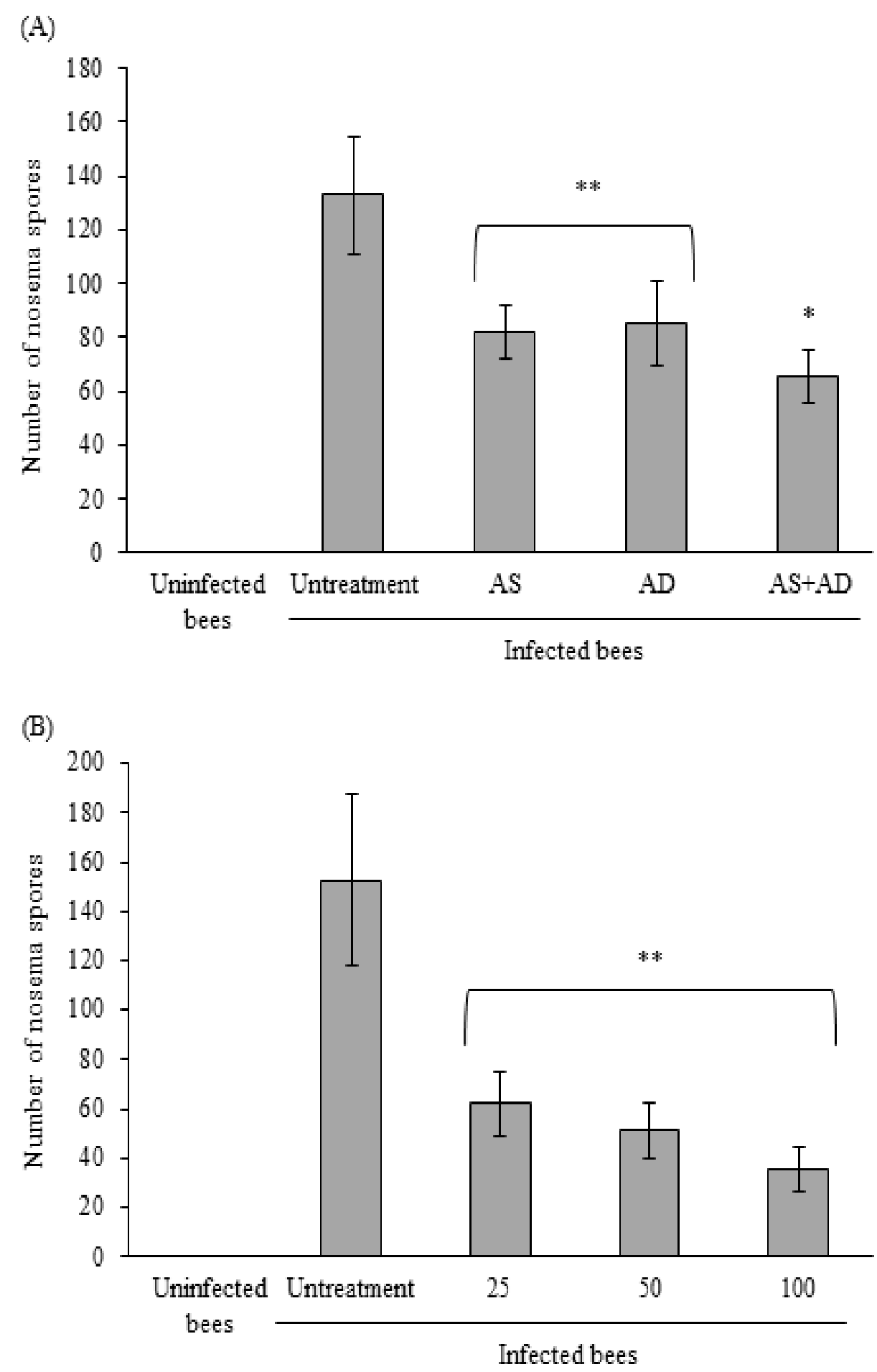

Fig. 6. In vivo activity of $A$. dubia (AD) and $A$. scaber (AS). (A) Infected bees by $N$. ceramae were treated with $25 \mu$ g/ $\mathrm{ml} A S, A D$, or $A S+A D$ in a $60 \%$ sucrose solution for 10 days. The spores, which were derived from the midgut, were counted using a hemocytometer. (B) Infected bees were treated with various concentrations of AS+AD. The values that are shown are the means \pm SDs of the three independent experiments. **p $<0.01$ as compared to the untreated bees.

AS decreased the percentage of live bees to influence the survival rate of the normal bees $85 \%$ and $67 \%$, respectively. Feeding 50 and at any of the concentrations.

$100 \mu \mathrm{g} / \mathrm{ml}$ of $A D$ also decreased the percent of To demonstrate the in vivo anti-nosemosis live bees to $89 \%$ and $78 \%$, respectively. Inter- activity of $A S$, and $A D$, we artificially inoculated estingly, feeding a mixture of AS + AD did not Nosema spores $\left(1 \times 10^{7}\right.$ spores $\left./ \mathrm{ml}\right)$ of $A S$, and 


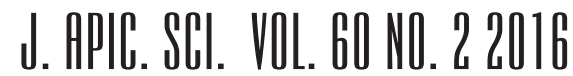

separately of $A D$, into 100 bees. All of the uninfected bees survived until the end of the experiment, but only $20 \%$ of bees that received no treatment after infection survived. Bees receiving $25 \mu \mathrm{g} / \mathrm{ml}$ of $A S$, and bees receiving $25 \mu \mathrm{g} / \mathrm{ml}$ of AD had survival rates of $52.5 \%$ and $58 \%$, respectively, on Day 10 (Fig. 5). Interestingly, the mixture of $A S+A D$ increased the survival rate of Nosema spore-infected bees to $78.1 \%$. Nosema spores were observed in all dead bees in the infected groups.

$N$. ceranae development was monitored as the number of spores present in the midgut of surviving bees at the end of the experiment (Day 10) (Fig. 6). The statistical analyses revealed that the spore content was higher in the infected control group (untreated) than it was in infected bees that were fed $25 \mu \mathrm{g} / \mathrm{ml}$ of AS, AD, or AS+AD. The best inhibition of Nosema proliferation was observed in the AS+AD treatment group (a reduction of $\sim 51 \%$ ). The honey bees supplemented with a single extract (a reduction of $37 \%$ (AS) or $35 \%$ (AD)) also presented a significant decrease in their Nosema spore load. As shown in Fig. 6(B), honey bees supplemented with the $A S+A D$ combination presented a significant decrease in the number of spores in a dose-dependent manner. Surprisingly, $100 \mu /$ $\mathrm{ml}$ of $A S+A D$ induced a reduction in the parasite load until $77 \%$, without in vivo toxicity.

\section{DISCUSSION}

In this study, we demonstrated that, depending on the dosage, $A$. scaber extracts as well as $A$. dubia extracts were effective at inhibiting the in vitro and in vivo development of $N$. ceranae. To the best of our knowledge, our study is the first report on the antimicrosporidian activity of $A$. scaber, and $A$. dubia. Although anti-nosemosis activity of $A$. dubia has not been reported, an ethanol extract of Artemisia absinthium, which is included in Artemisia species like $A$. dubia, has been tested against Nosemaspecies (Pohorecka, 2004; Porrini et al., 2011). But, there is controversy about the anti-nosemosis activity of A. absinthium. Pohorecka (2004) firstly verified anti-nosemosis activity of $A$. absinthium with
$5 \%$ and $10 \%$ extracts on bees both naturally and artificially infected with $N$. apis spores, but A. absinthiumalso had a harmful impact on these insects (Pohorecka, 2004). On the other hand, Porrini et al. (2011) found that an extract of $A$. absinthium did not diminish the spore load of $N$. ceranae infection throughout their experiment, even at the highest concentration (10\%). They also reported another new plant (Laurus nobilis) for the inhibition of $N$. ceranae development (Porrini et al., 2011). An extract of L. nobilis at a $1 \%$ concentration inhibited the in vivo development of $N$. ceranae. Furthermore, L. nobilis extract also showed a low toxicity during the assay. The differences between the two studies (Pohorecka, 2004; Porrini et al., 2011) could be explained by the difference in plant extracts' susceptibility to Nosema species ( $N$. apis vs $N$. ceranae) or by the extraction method used for the plants (Ahameethunisa \& Hopper, 2010; Tariq et al., 2009).

The bioactivity of $A$. scaberand $A$. dubiaextracts against other pathogens, such as viruses (Kwon et al., 2000) and bacteria (Satyal et al., 2012), has also been reported. In traditional eastern medicine, $A$. scaber is known to have various medicinal effects. Minced $A$. scaber has been spread on the skin to treat external injuries. Previous studies have demonstrated the effects of an aqueous extract of $A$. scaber on the immune system via enhanced macrophage activation in mice. This extract strangely increased the production of pro-inflammatory cytokines (TNF- $\alpha, \mathrm{IL}-1 \beta, \mathrm{IL}-6)$, nitric oxide, and cyclooxigenase-2 (Kim et al., 2009). A. scaber extract also showed anti-oxidant activities depending on the manufacturing process (Kim, Choi, \& Park, 2014). Even an anti-HIV-1 effect was revealed for treatment using $A$. scaber derived caffeoyl quinic acid (Kwon et al., 2000). In addition to the herbs, a few chemicals have been reported as anti-nosemosis therapeutic compounds. Representative examples may include oxalic acid and acetic acid. Nanetti et al. (2015) tested the efficacy of an oxalic acid solution against artificial and natural infections. In an in vitro study, the administration of oxalic acid hindered the development of $N$. ceranae 
infections compared to the untreated controls, which confirmed the results obtained in the field. When oxalic acid was administered to free flying colonies twice, the infection prevalence decreased in both young and old bees. At the same time, an increased prevalence in all the untreated controls was detected. Interestingly, the bees treated with oxalic acid overwintered healthily, but the untreated ones did not. Traditionally, acetic acid has been used to disinfect honeycombs to remove Nosema spores, but this has not been verified in scientific experiments. Fumagillin, an antibiotic isolated from the fungus $A$. fumigatus, has been the only widely used method to treat colonies infected with Nosema species in western honey bees, $A$. mellifera (Bailey, 1953; Higes et al., 2011). It is considered to be the most effective medication for $N$. apis infection in honey bees (Bailey, 1953). However, in contrast to fumagillin's efficacy against $N$. apis in honey bees, $N$. ceranae might evade fumagillin (Huang et al., 2013; Williams et al., 2008) therefore, this drug may be inappropriate for the treatment of $N$. ceranae infections. It may be inappropriate, even though previous reports have shown that fumagillin treatment of colonies infected with $N$. ceranae was effective (Botías et al., 2013; Higes et al., 2008). It has even been considered that fumagillin can contribute to a higher incidence rate and pathogenicity of $N$. ceranae (Huang et al., 2013). For these reasons, most researchers want to find a new agent to use against $N$. ceranae.

Several antimicrobial agents (albendazole, ornidazole, tinidazole, and metronidazole) were tested to determine their activity against $N$. ceranae in Nosema spore-infected cells and therefore to identify new drugs with antinosemosis activity that is comparable to that of fumagillin. The antimicrobial agents were selected based on their well-known inhibitory effects on other fungi and microsporidia. Albendazole had no significant in vitro activity against $N$. ceranae, and ornidazole also had no significant in vitro activity against $N$. ceranae. At a concentration of $2 \mathrm{mg} / \mathrm{ml}$, tinidazole or metronidazole can completely inhibit $N$. ceranae infection of IPL cells similar to the activity of fumagillin in vitro. However, both substances are unlikely to have a future as anti-nosemosis drugs in honey bees because many countries prohibit the use of nitroimidazoles in domestic animals (Payne et al., 1999).

In this study, we identified two anti-nosemosis plants, $A$. scaber, and $A$. dubia, which when separately used had reduced the spore development of $N$. ceranae in spore-infected cells. The most important finding was that these plants were effective at non-toxic concentrations. Anti-nosemosis activities of both plants were revealed in a honey bee experiment. Specifically, the mixture containing both $A$. scaber $+A$. dubia showed stronger activity than treatment with only a single plant. However, the mechanisms of action of $A$. scaber, and the mechanisms of action of $A$. dubia against $N$. ceranae are still unclear. Further research will be necessary to determine the identity of these active compounds. Our results suggest new possibilities for medicaments and therapeutic methods to control N. ceranae infection in honey bees.

\section{ACKNOWLEDGEMENTS}

This research was financially supported by the Ministry of Trade, Industry and Energy (MOTIE) and Korea Institute for Advancement of Technology (KIAT) through the Research and Development for Regional Industry.

\section{REFERENCES}

Ahameethunisa, A. R. \& Hopper W. (2010). Antibacterial activity of Artemisia nilagirica leaf extracts against clinical and phytopathogenic bacteria. BMC complementary and alternative medicine, 10, 6 . DOl:10.1186/1472-6882-10-6

Bailey, L. (1953). Effect of Fumagillin upon Nosema apis (Zander). Nature, 171, 212-213.

Becker, H., Scher, J. M., Speakman, J. B., \& Zapp J. (2005). Bioactivity guided isolation of antimicrobial compounds from Lythrum salicaria. Fitoterapia, 76(6), 580-584. D0l:10.1016/ifitote.2005.04.011 
Botías, C., Martín-Hernández, R., Meana, A., Higes, M. (2013). Screening alternative therapies to control Nosemosis type C in honey bee (Apis mellifera iberiensis) colonies. Research in Veterinary Science, 95(3), 1041-1045. Dol:http://dx.doi.org/10.1016/j. rvsc.2013.09.012

Calderone, N. W. (2012). Insect pollinated crops, insect pollinators and US agriculture: trend analysis of aggregate data for the period 1992-2009. PloS one, 75), e37235. D0l:10.1371/journal.pone.0037235

Chen, Y. P." \& Huang, Z. Y. (2010). Nosema ceranae, a newly identified pathogen of Apis mellifera in the USA and Asia. Apidologie, 47(3), 364-374. DOl:10.1051/apido/2010021

de Graaf, D. C., Masschelein, G., Vandergeynst, F., De Brabander, H. F., \& Jacobs, F. J. (1993). In Vitro Germination of Nosema apis (Microspora: Nosematidae) Spores and Its Effect on Their $\alpha \alpha$-Trehalose/d-Glucose Ratio. Journal of Ivertebrate Pathology, 62(3), 220-225. DOl:http://dx.doi. org/10.1006/jipa.1993.1103

Fries, I. (2010). Nosema ceranae in European honey bees (Apis mellifera). Journal of Invertebrate Pathology, 103(1), 73-79. D0l:10.1016/j.jip.2009.06.017

Genersch, E., von der Ohe, W., Kaatz, H., Schroeder, A., Otten, C., Büchler, R., ... Rosenkranz, P. (2010). The German bee monitoring project: a long term study to understand periodically high winter losses of honey bee colonies. Apidologie, 47(3), 332-352. DOl:10.1051/apido/2010014

Gisder, S., Hedtke, K., Mockel, N., Frielitz, M. C., Linde, A., Genersch, E. (2010). Five-year cohort study of Nosema spp. in Germany: does climate shape virulence and assertiveness of Nosema ceranae? Applied and environmental microbiology, 76(9), 30323038. D0l:10.1128/AEM.03097-09

Gisder, S., Mockel, N., Linde, A., \& Genersch, E. (2011). A cell culture model for Nosema ceranae and Nosema apis allows new insights into the life cycle of these important honey bee-pathogenic microsporidia. Environmental Microbiology, 13(2), 404-

\section{DOl:10.1111/j.1462-2920.2010.02346.x}

Helvaci, S., Kokdil, G., Kawai, M., Duran, N., Duran, G., Guvenc, A. (2010). Antimicrobial activity of the extracts and physalin D from Physalis alkekengi and evaluation of antioxidant potential of physalin D. Pharmaceutical biology, 48(2), 142-150. DOl:10.3109/13880200903062606

Higes, M., Martín-Hernández, R., Botías, C., Bailón, E. G., González-Porto, A. V., Barrios, L., ... Meana, A. (2008). How natural infection by Nosema ceranae causes honeybee colony collapse. Environmenta/Microbiology, 1010), 2659-2669. DOl:10.1111/j.14622920.2008.01687.x

Higes, M., Martin, R., \& Meana, A. (2006). Nosema ceranae, a new microsporidian parasite in honeybees in Europe. Journal of Invertebrate Pathology, 92(2), 93-95. D0l:10.1016/j.jip.2006.02.005

Higes, M., Nozal, M. J., Alvaro, A., Barrios, L., Meana, A., Martín-Hernández, R., Bernal, J. L., Bernal, J. (2011). The stability and effectiveness of fumagillin in controlling Nosema ceranae (Microsporidia) infection in honey bees (Apis mellifera) under laboratory and field conditions. Apidologie, 42(3), 364-377. D0l:10.1007/s13592-011-0003-2

Huang, W.-F., Solter, L. F., Yau, P. M., Imai, B. S. (2013). Nosema ceranae Escapes Fumagillin Control in Honey Bees. PLOS Pathogens, 9(3), el003185. D0l:10.1371/journal.ppat.1003185

Johnson, M., Wesely, E. G., Kavitha, M. S., Uma, V. (2011). Antibacterial activity of leaves and inter-nodal callus extracts of Mentha arvensis L. Asian Pacific Journal of Tropical medicine, 4(3), 196-200. D0l:10.1016/ S1995-7645(11)60068-0

Kim, D. H., Kim, Y. C., \& Choi, U. K. (2011). Optimization of antibacterial activity of Perilla frutescens var. acuta leaf against Staphylococcus aureus using evolutionary operation factorial design technique. International Journal of Molecular Sciences, 12(4), 2395-2407. DOl:10.3390/ijms12042395

Kim, G.-H., Choi, H.-Y., \& Park, H. S. (2014). Antioxidant 


\section{LEE ET Hl.}

Activity of Aster scaber Thunb. With Different Cooking Methods (LB409). The FASEB Journal, 28, LB409

Kim, J., Park, C. S., Lim, Y., Kim, H. S. (2009). Paeonia japonica, Houttuynia cordata, and Aster scaber water extracts induce nitric oxide and cytokine production by lipopolysaccharide-activated macrophages. Journal of medicinal food, 12(2), 365-373. D01:10.1089/ jmf.2008.1013

Kwon, H. C., Jung, C. M., Shin, C. G., Lee, J. K., Choi, S. U., Kim, S. Y., Lee K. R. (2000). A new caffeoyl quinic acid from aster scaber and its inhibitory activity against human immunodeficiency virus-1 (HIV-1) integrase. Chemical \& pharmaceutical bulletin, 48(11), 17961798.

Liu, M. L., Li, M. L., \& Hu, S. K. (1983). Study of antibacterial and antiinflammatory components of Achillea alpina. Journal of traditional Chinese medicine, 3(3), 213-216.

Mocan, A., Crisan, G., Vlase, L., Crisan, O., Vodnar, D. C., Raita, O., ... Tilea, I. (2014). Comparative studies on polyphenolic composition, antioxidant and antimicrobial activities of Schisandra chinensis leaves and fruits. Molecules, 1999), 15162-15179. D01:10.3390/ molecules190915162

Nanetti, A., Rodriguez-García, C., Meana, A., Martín-Hernández, R., Higes, M. (2015). Effect of oxalic acid on Nosema ceranae infection. Research in Veterinary Science, 102, 167-172. DOl:http://dx.doi. org/10.1016/j.rvsc.2015.08.003

Payne, M. A., Baynes, R. E., Sundlof, S. E., Craigmill, A., Webb, A. l., \& Riviere, J. E. (1999). Drugs prohibited from extralabel use in food animals. Journal of the American Veterinary Medical Association, 215(1), 28-32.

Pohorecka, K. (2004). Laboratory studies on the effect of standardized Artemisia absinthiumL. extract on Nosema apis infection in the worker Apis mellifera. Journal of Apicultural Science, 48(2), 131-136.

Porrini, M. P., Fernández, N. J., Garrido, P. M., Gende, L. B., Medici, S. K., \& Eguaras, M. J. (2011). In vivo evalu-
Anti-nosemosis activities

ation of antiparasitic activity of plant extracts on Nosema ceranae (Microsporidia). Apidologie, 42(6), 700-707. DOl:10.1007/s13592-011-0076-y

Satyal, P., Paudel, P., Kafle, A., Pokharel, S. K., Lamichhane, B., Dosoky, N. S., ... Setzer, W. N. (2012). Bioactivities of volatile components from Nepalese Artemisia species. Natural Product Communications, 712), 1651-1658.

Silva, A. C., Santana, E. F., Saraiva, A. M., Coutinho, F. N., Castro, R. H., ... Albuquerque, U. P. (2013). Which approach is more effective in the selection of plants with antimicrobial activity? Evidence-based Complementary and Alternative Medicine, 2013, 308980. DOl:10.1155/2013/308980

Tariq, K. A., Chishti, M. Z., Ahmad, F., Shawl, A. S. (2009). Anthelmintic activity of extracts of Artemisia absinthium against ovine nematodes. Veterinary Parasitology, 1601-2), 83-88. D0l:10.1016/j.vetраг.2008.10.084

Whittington, R., \& Winston, M. L. (2003). Effects of Nosema bombiand its treatment fumagillin on bumble bee (Bombus occidentalis) colonies. Journal of Invertebrate Pathology, 84(1), 54-58.

Williams, G. R., Sampson, M. A., Shutler, D., \& Rogers, R. E. (2008). Does fumagillin control the recently detected invasive parasite Nosema ceranae in western honey bees (Apis mellifera)? Journal of invertebrate pathology, 99(3), 342-344. D0l:10.1016/j. jip.2008.04.005

Williams, G. R., Shutler, D., Burgher-MacLellan, K. L., Rogers, R. E. (2014). Infra-population and -community dynamics of the parasites Nosema apis and Nosema ceranae, and consequences for honey bee (Apis mellifera) hosts. PloS one, 977), e99465. DOl:10.1371/journal.pone.0099465 